\title{
IMPACT OF BIOCHAR AND ANIMAL MANURE ON SOME BIOLOGICAL AND CHEMICAL PROPERTIES OF SOIL
}

\author{
IRMAK YILMAZ, F. - ERGUN, Y. A. \\ Department of Soil Science and Plant Nutrition, Faculty of Agriculture, Ordu University, Ordu, \\ Turkey \\ *Corresponding author \\ e-mail: fundairmak@hotmail.com; phone: +90-452-234-5010; fax: +90-452-226-5269 \\ (Received $15^{\text {th }}$ Mar 2019; accepted 24 $4^{\text {th }}$ May 2019)
}

\begin{abstract}
The aim of this study was to show the relationship between tomato plants grown in soil in different doses of animal manure (AM) and biochar (BC) obtained from hazelnut shell with some soil enzymes, $C$ mineralization, microbial biomass and other soil properties. In this context, 0-5-10-15-20 ton/ha biochar (BC) obtained from hazelnut shell and 5-10-20 ton/ha mature animal manure were applied into the soil. The study repeating 6 times was performed in natural conditions of greenhouse according to the study design of random parcels. Some chemical soil properties (organic material, total N, available $\mathrm{P}$ and $\mathrm{K}$ ) and some soil enzymes of tomato (Lycopersicum esculentum Mill) plant grown in biochar and animal manure applied-soil (dehydrogenase, urease, arylsulfatase and alkaline phosphatase) were identified. Biochar and animal manure applications increased dehydrogenase, urease and arylsulfatase enzyme activities of the soil and it was statistically significant $(p<0.01)$. The activity of alkaline phosphatase enzyme increased but and it was not statistically significant. The biological analyses of the soil showed that the most effective dose varies in each parameter, but it was identified that $\mathrm{BC}_{5}+\mathrm{AM}_{5}, \mathrm{BC}_{15}+\mathrm{AM}_{5}, \mathrm{BC}_{20}$ and $\mathrm{AM}_{20}$ doses increased the biological properties. The study showed that biochar and animal manure applications increased the organic material contents of soil and the available macro contents including nitrogen $(\mathrm{N})$, phosphor $(\mathrm{P})$ and potassium $(\mathrm{K})$.
\end{abstract}

Keywords: animal manure, nutrition element, biochar, enzyme activity, microbial activity, organic material

\section{Introduction}

The human population increases with a geometric array, and the food demand also rises inevitably at the same speed. The effort to meet the food demand as fast as possible has led to the introduction of a wide range of chemical inputs into the agricultural production processes. Types of chemical manure are a factor accelerating production significantly, however, the destructive aspect for the environment and human health has become a disadvantage in the long term, and the scientists are looking for solutions. Accordingly; organic soil regulators which are compatible with nature, also beneficial for the environment and human health, yielding effective results in agricultural applications in a narrow field, aiming to minimize the use of chemical manure with the same productive capacity for animal and plant production are evaluated. The important preventive measures for food crisis that threatens the future of human life include increasing the amount of organic material in agricultural soils and the use of agricultural methods for the protection, preservation and maintenance of suitable environment for soil organisms. The use of organic manure instead of the chemical manure in organic agriculture helps to increase soil organic materials and microbiological activity. The aim of organic agriculture is to protect the health of the plant, environment, human and animal without causing water, soil and air pollution (Kizllaslan and Olgun, 2012). Besides the natural manuring system, some side products have been tested to improve quality; the most commonly used herbal and woody wastes among these side products are also 
preferred to be burnt on agricultural soil for reversible soil recovery without environmental pollution. The aim of this application is to provide available plant nutrition elements and to eliminate environmental pollution caused by woody side products of the residues in agricultural soils by pyrolysis method. The new product containing high carbon and mineral material obtained as a result of pyrolysis of organic substances in the oxygen-free environment or gasification by reduced oxygen is called biochar (Lehmann, 2007), and based on its history, it has been used to support organic manures, and to increase productivity in agricultural soils effectively. Pioneering research on the abovementioned organic soil regulator were performed for seedling cultivation (Retan, 1915) and soil chemistry (Tyron, 1948). Much earlier than the those researches, waste biomass charcoal was used as a manure in an application carried out in China (Liebig, 1878). Biochar-based researches have been remarkably increased in Japan starting from the first quarter of the 80s (Kishimoto and Sugiura, 1980). Despite of all these researches, global interest in biochar was especially rised in the second quarter of the 2000s, but recognized recently in Turkey. When a biochar rich in organic carbon is burnt, an ash consisting of $\mathrm{Ca}, \mathrm{Mg}$ and inorganic carbonate is obtained. This high-carbon organic regulator is defined as an aromatic material consisting of six chains of carbon atoms connected to each other without oxygen and hydrogen. Carbon atoms connected to each other without oxygen and hydrogen is considered as advantageous due to absence of more atoms in organic material (Roberts et al., 2009). The highest quality criteria for Biochar includes: high cation exchange capacity, adsorption and low portability of components (Glaser et al., 2002; Liang et al., 2006; McClellan et al., 2007; McLaughlin et al., 2009). The research was conducted to evaluate whether the hazelnut shell without commercial value could be used for other purposes except for fuel in the study region (Central and East Black Sea Region). The aim of the research is to show the relationship between tomato plants grown in soil in different doses of animal manure (AG) and biochar (BC) obtained from hazelnut shell with some soil enzymes, $\mathrm{C}$ mineralization, microbial biomass and other soil properties.

\section{Material and method}

\section{Study area}

The experiment was carried out in the high tunnel greenhouse established in Ordu University experiment area. The study area is located in Ordu province, Altınordu district, Eastern Black Sea Region, Turkey in 2016. The province of Ordu is located between the northern latitudes of 4464031-4551905 with eastern longitudes of 304670-420033 (Fig. 1).

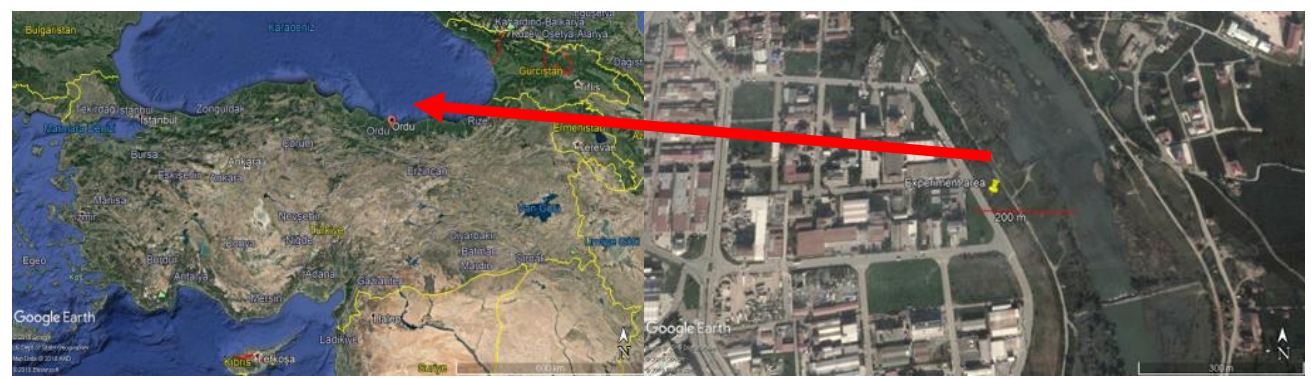

Figure 1. Map shows the location of Ordu University experiment area in the Ordu Province, Turkey 


\section{Materials and methods}

In the study performed under the conditions of the greenhouse, soil with clayey texture from a depth of 0-30 was used. As an organic material, the hazelnut shell of Ordu has been transformed into biochar. Production temperature for biochar production is $380{ }^{\circ} \mathrm{C}$; the production time is $270 \mathrm{~min}$ (Fig. 2). The production continued until the end of the gas outlet, including flammable gases from the system. The mature animal manure was obtained from the farmer in Ordu province Mesudiye district. Alsancak tomato seedling was used as a plant material. Before the experiment was established, some basic physical and chemical analyses of the soil sample were performed (Table 1.)

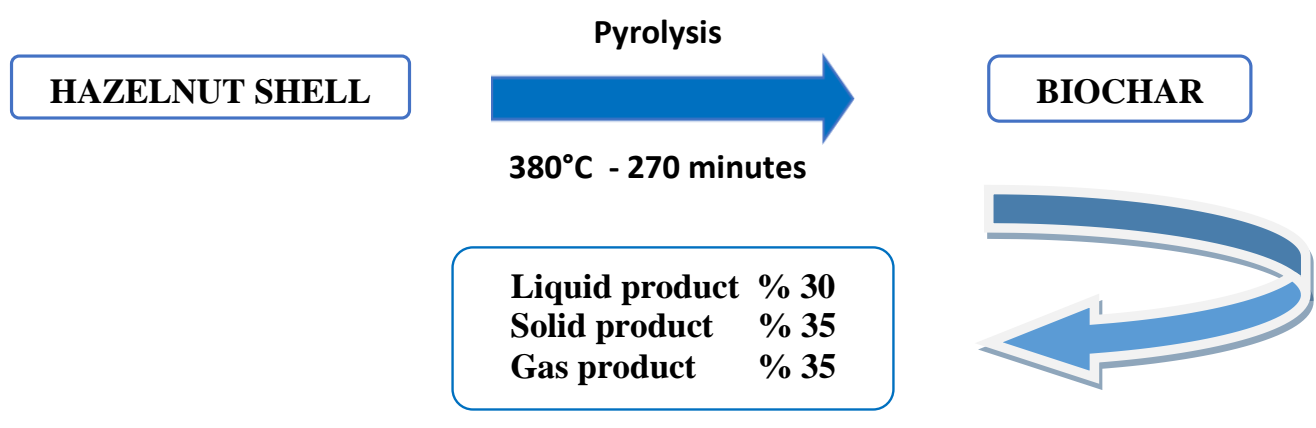

Figure 2. Biochar pyrolysis process obtained from hazelnut shell (Ronsse et al., 2013)

\section{Pyrolysis}

The process results in the formation of three main products: carbon-rich solid product (biochar), a volatile matter which can further be partially condensed to liquid phase (bio-oil), and the remaining so-called "non-condensable" gases, like $\mathrm{CO}, \mathrm{CO}_{2}$, $\mathrm{CH}_{4}$, and $\mathrm{H}_{2}$ (Kambo and Dutta, 2015).

The soil used in the experiment had a clayey structure, having $\mathrm{pH}$ value of (6.46) mild acid without saltiness problem. The level of organic material was $1.8 \%$, total $\mathrm{N}$ content was $0.045 \%, \mathrm{P}$ content was $6.7 \mathrm{mg} \mathrm{kg}^{-1}$ and $\mathrm{K}$ content was $57.1 \mathrm{mg} \mathrm{kg}^{-1}$.

Mature animal manure and biochar, used as organic material, are materials of organic origin, and their properties complement each other. Some chemical and physical properties belonging to the burnt animal manure and biochar used in the experiment is presented in Table 1.

Table 1. Some physical and chemical properties of the soil used in the experiment and biochemical and vermicompost properties

\begin{tabular}{c|c|c|c|c|c|c|c|c}
\hline Material & $\begin{array}{c}\mathbf{O . M} \\
(\boldsymbol{\%})\end{array}$ & $\begin{array}{c}\mathbf{C} \\
(\boldsymbol{\%})\end{array}$ & $\begin{array}{c}\mathbf{N} \\
(\boldsymbol{\%})\end{array}$ & $\mathbf{p H}$ & $\begin{array}{c}\mathbf{K} \\
\left(\mathbf{m g ~ k} \mathbf{~ g}^{-1}\right)\end{array}$ & $\begin{array}{c}\mathbf{P} \\
\left(\mathbf{m g ~ k g}^{-1}\right)\end{array}$ & $\begin{array}{c}\mathbf{M g} \\
\left(\mathbf{m g ~ k g}^{-\mathbf{1}}\right)\end{array}$ & $\begin{array}{c}\mathbf{F e} \\
\left(\mathbf{m g ~ k g}^{-\mathbf{1}}\right)\end{array}$ \\
\hline Soil & 1.8 & - & 0.045 & 6.46 & 57.1 & 6.7 & 120 & 8.6 \\
AM & & 26.4 & 1.32 & 7.6 & 1.24 & 1.12 & - & - \\
BC & & 81 & 1.17 & 9.24 & 0.33 & - & 1690 & 10.4 \\
\hline
\end{tabular}

\section{Experimental design}

In the research, $2 \mathrm{~mm}$ grated 2 different organic material (biochar and animal manure) $0-5-10-15-20$ ton/ha hazelnut biochar and 5-10-20 ton/ha mature animal 
manure doses were used proportionately 6 times according to the study design of random parcels in natural conditions of greenhouse (Table 2). In addition, \% AM and \% $\mathrm{BC}$ doses were applied to see the effects alone. After the mixtures were prepared and filled separately in the air dry $3 \mathrm{~kg}$ soil flowerpots, they were kept for $24 \mathrm{~h}$ in order to stabilize the internal dynamics in the medium. At the end of $24 \mathrm{~h}$, Alsancak tomato seedlings, which is used as a plant material, were planted as 1 seedling per flowerpot. During planting, $\mathrm{K}_{2} \mathrm{HPO}_{4} 100 \mathrm{ppm} \mathrm{K} /$ pot and $125 \mathrm{ppm} \mathrm{P} /$ pot and $100 \mathrm{ppm} \mathrm{N} / \mathrm{pot}$ manures as $\mathrm{Ca}\left(\mathrm{NO}_{3}\right)_{2}$ form were applied as a basic manuring. After this process, all flowerpots are irrigated. Irrigation is performed periodically according to weather conditions and soil humidity. Watering was conducted according to plant water demand. The average temperature during the trial is $22.7^{\circ} \mathrm{C}$ degrees. At the end of 1 week, regularly inspected and irrigated plants have begun to grown, each seedling was observed until the flowering period. Plants were harvested during flowering period.

Table 2. Potted trial applications

\begin{tabular}{c|c}
\hline Mediums & \\
\hline $\mathrm{C}$ & Control \\
$\left(\mathrm{BC}_{5}+\mathrm{AM}_{5}\right)$ & $10 \mathrm{gr} \mathrm{BC}-10 \mathrm{gr} \mathrm{AM}$ \\
$\left(\mathrm{BC}_{5}+\mathrm{AM}_{10}\right)$ & $10 \mathrm{gr} \mathrm{BC}-20 \mathrm{gr} \mathrm{AM}$ \\
$\mathrm{BC}_{10}+\mathrm{AM}_{5}$ & $20 \mathrm{gr} \mathrm{BC}-10 \mathrm{gr} \mathrm{AM}$ \\
$\left(\mathrm{BC}_{10}+\mathrm{AM}_{10}\right)$ & $20 \mathrm{gr} \mathrm{BC}-20 \mathrm{gr} \mathrm{AM}$ \\
$\left(\mathrm{BC}_{15}+\mathrm{AM}_{5}\right)$ & $30 \mathrm{gr} \mathrm{BC}-10 \mathrm{gr} \mathrm{AM}$ \\
$\left(\mathrm{BC}_{15}+\mathrm{AM}_{10}\right)$ & $30 \mathrm{gr} \mathrm{BC}-20 \mathrm{gr} \mathrm{AM}$ \\
$\mathrm{BC}_{20}$ & $40 \mathrm{gr} \mathrm{BC}$ \\
$\mathrm{AM}_{20}$ & $40 \mathrm{gr} \mathrm{AM}$ \\
\hline
\end{tabular}

\section{Soil physicochemical analyses}

Soil samples $2 \mathrm{~mm}$ grated were waited and prepared for the analyses in $+4{ }^{\circ} \mathrm{C}$ refrigerator immediately after, and biological analyses were initiated. To identify the properties of sample soil, the texture was examined by hydrometer method as told by Bouyoucos (1962), soil reaction $(\mathrm{pH})$ and saltiness (EC) by U.S. Salinity Laboratory Staff (1954), organic material by Nelson and Sommers (1982), total nitrogen by Bremner (1965), useful phosphor by Olsen et al. (1954), useful potassium by Knudsen et al. (1982) as told by Müftüoğlu et al. (2012).

\section{Soil biological analyses}

For the biological analyses of the soil; $\mathrm{CO}_{2}$ production was identified by the method told by Isermeyer (1952); microbial biomas-C by Anderson and Domsch (1978), dehydrogenase enzyme activity by Thalmann (1968), urease enzyme activity by Kandeler and Gerber (1988), alkalin phosphatase enzyme activity by Tabatabai and Bremner (1969), arylsulfatase enzyme activity by Tabatabai and Bremner (1970) as told by Schinner et al. (1996). For the organic materials in PH and EC 1:3 ratio organic material-pure water mixture in the study (Gabriels and Verdonck, 1992), organic material was burnt at $550 \pm 25^{\circ} \mathrm{C}$ for $4 \mathrm{~h}$ by the method of Kacar (2009); plant nutrition 
element analyses were performed in organic materials by the methods told by Kacar and Kütük (2010).

\section{Statistical analysis}

At the end of the study, the variance analysis of the obtained data was performed using the JMP package program and the important results were evaluated according to the LSD test.

\section{Results and discussion}

\section{The effect of organic materials on some enzyme activity of the soils}

Different doses of biochar and animal manure applications affected and increased the dehydrogenase enzyme activity in the soils favorably; it was found that application are statistically significant at level $1 \%$, and dehydrogenase enzyme activity values of the soils were between 3.16-40.03 mg TPF/g.k.t. The lowest dehydrogenase activity value was in the control application the highest was in $\mathrm{BC}_{10}+\mathrm{AM}_{5}$ application (Fig. 3a). This application yielded 12.7 fold increase. When the applications into the soil were evaluated numerically, it was observed that the most effective applications were $\mathrm{BC}_{10}+\mathrm{AM}_{5}, \mathrm{BC}_{10}+\mathrm{AM}_{10}, \mathrm{BC}_{15}+\mathrm{AM}_{5}$ and $\mathrm{BC}_{15}+\mathrm{AM}_{10}$. Single $\mathrm{BC}_{20}$ and $\mathrm{AM}_{20}$ applications increased dehydrogenase enzyme activity values less than the application comparing $\mathrm{BC}$ and $\mathrm{AM}$. The organic materials added to the application have been used as a source of nutrients and energy by microorganisms living in soil.

Paz-Ferreiro et al. declared that (2012) when biochar in different doses obtained from waste sludge is applied to the soil, it increases the activity by 2.8 times compared to the control, however, Park et al. declared that (2011) biochar obtained from the chicken manure increases the dehydrogenase enzyme activity when applied into the soil in increased doses.

The statistical evaluations showed that the effects of the applications on the urease enzyme activity are significant $(\mathrm{p}<0.01)$. Biochar and animal manure applications increased urease enzyme activity in soil (0.28), the highest value was obtained for $\mathrm{BC}_{5}+\mathrm{AM}_{5}$ and $\mathrm{BC}_{15}+\mathrm{AM}_{5}$ applications (0.90) (Fig. 3b). $\mathrm{BC}_{5}+\mathrm{AM}_{5}$ and $\mathrm{BC}_{15}+\mathrm{AM}_{5}$ applications into the soil increased urease enzyme activity by 3.2 times compared to the control. Kablan (2005) declared that urea, as a substrate source of microorganisms producing urease enzyme, has increased with organic $\mathrm{N}$ forms, which are substrates of $\mathrm{N}$ content in different organic wastes. Since biochar has a wide $\mathrm{C} / \mathrm{N}$ ratio, it is subjected to more fragmentation by microorganisms, resulting in the increase of these enzymes. Nannipieri et al. (1990) showed that the final process of urease, which is the organic phase of organic nitrogen mineralization in soil, is the separation of urea and the responsible enzyme is urease (Kablan, 2005). These enzymes are produced by soil microorganisms in order to break down their nutrient materials, then are kept by colloids such as clay and organic material of the soil, and can sustain their activities without being attached to the microorganism cell that produces these enzymes (Aşkın et al., 2004).

Akça and Namli declared that (2015) after biochar is applied to the tomato plant, the urease enzyme activity is meaningfully and significantly increased by $5 \%$ as compared to the control and chemical manual. It was observed that urease enzyme activity of the soil has a significant relationship with important soil properties such as organic 
material, soil texture, $\mathrm{pH}$ cation exchange capacity, and that the organic wastes added to the soil significantly increase urease enzyme activity (Özdemir et al., 2000). The researches declared that when rapid weatherable organic materials are added into the soil, urease activity may be increased by the stimulation of microbial activity. Moreno et al. (1999) declared that when organic materials are added to the soil, the urease activity increases remarkably. On the contrary, Azam and Malik (1985) reported that organic materials did not affect the urease activity. Biochar and animal manure applications increased arylsulfatase enzyme activity in the soil; arylsulfatase enzyme activity values of the soils were $0.07-0.15 \mu \mathrm{g} P-\mathrm{N}$ g.k.t ${ }^{-1}$. The lowest value was at control application, the highest was at $\mathrm{BC}_{5}+\mathrm{AG}_{5}$ application; this application yielded 2.2 fold increases. Arylsulfatase enzyme has a key role in $\mathrm{S}$ cylce in terms of agricultural aspect. It acts as a catalyst for hydrolisation from assimilable organic $\mathrm{S}$ to the inorganic $S$ by the plant, and allows the nutrition element required for plant development to be faster and easier in the inorganic form (Kayıkçığlu and Okur, 2013). In a study on tomato plant, the biochar obtained from the litter of poultry in different doses has been applied as an application, and enzyme activities were increased significantly with biochar applications (Akça and Namli, 2015). In the experimental soils, tomato plant increased arylsulfatase enzyme activity as compared to the control (Fig. 3c). Because microbial activity increases in the presence of plant roots, increasing arylsulfatase enzyme activity (Kablan, 2005). Sun et al. (2014) reported that the addition of wood-originated biochar into the sandy agricultural soil does not increase the arylsulfatase enzyme activity too much; however, at the end of approximately 50 years, it contributes several enzymes of biological wastes such as arylsulfatase.
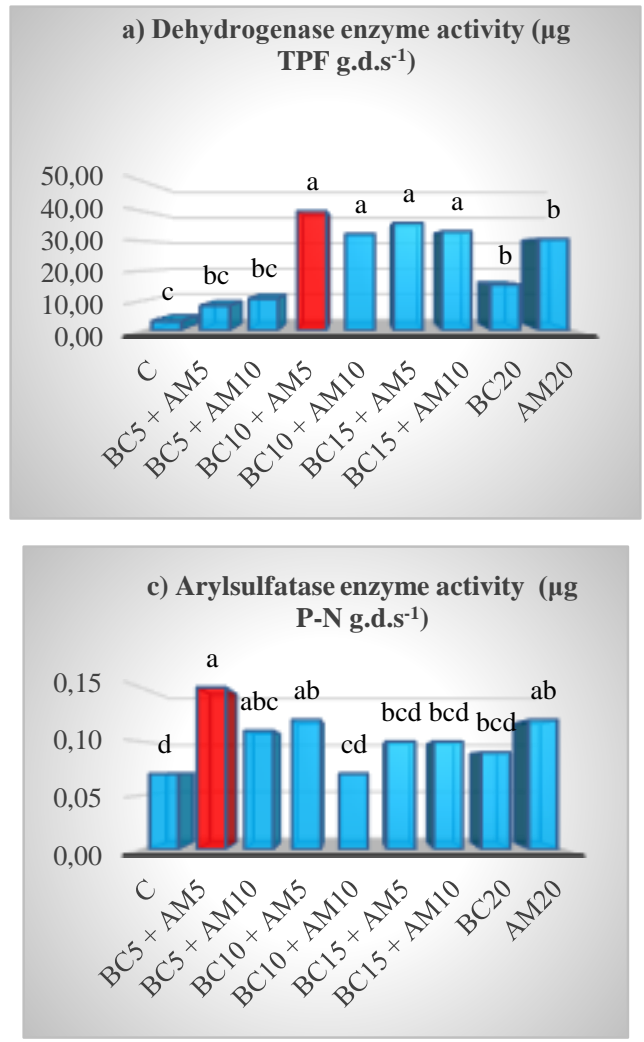
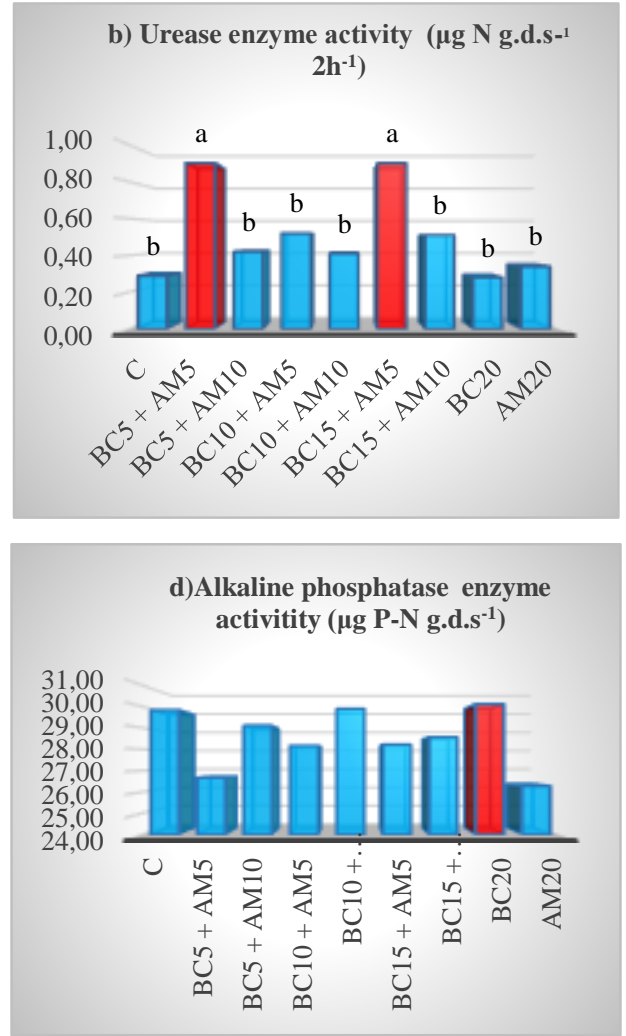

Figure 3. The effects of biochar and animal manure applied soils on dehydrogenase (a), urease (b), arylsulfatase (c) and alkaline phosphatase (d) enzyme activities (g.d.s : gram dry soil) 
The statistical evaluations showed that the effects of organic wastes on alkaline phosphatase enzyme activity are not significant. However, different doses of biochar and animal manure applications affected the alkaline phosphatase enzyme activity in the soil favorably, and increased numerically; alkaline phosphatase enzyme activity values were between 25.49 and $30.11\left(\mu \mathrm{g} P-\mathrm{N}\right.$ g.k.t $\left.{ }^{-1}\right)$. The lowest value was at control application, the highest was at $\mathrm{BC}_{20}$ application; this application yielded $18 \%$ increase (Fig. 3d). Phosphor uptake by the plants is performed via the mineralization of the organic phosphor compounds into orthophosphate by phosphatase enzymes. Alkaline phosphotases are secreted only by microorganisms, several bacterial strains produce alkaline phosphotase enzyme (Okur, 1997). It was observed that phosphatase enzyme activity was statistically insignificant, and did not increase in the soils, because if phosphatase is inhibited, $\mathrm{PO}_{4}{ }^{-3}$ synthesis is inhibited and, the formation of orthophosphate acid and alkaline phosphatase enzyme activity of organic phosphor compound is inhibited, meaning that phosphor mineralization is inhibited (Chunderova and Zubets, 1969).

\section{The effect of organic materials on several chemical properties of soils}

The effects of biochar and animal manure applications on the organic matter contents of soil are presented in Table 3. The statistical evaluations showed that the effects of biochar and animal manure on organic material are significant $(\mathrm{p}<0.05)$. The different doses of biochar and animal manure applications increased the organic material content of the soil; the amount of the organic material was increased by 1.80-6.92\% (Table 3). The lowest value was at control application, the highest was at $\mathrm{BC}_{15}+\mathrm{AM}_{10}$ application; this application yielded 3.84 fold increase in the organic materials. Mixing of these two materials (organic material and a material with high organic content) in the soil increased the amount of the organic materials in the soil, as expected. Demisie et al. (2014) reported in their study that when the biochar obtained from oak and bamboo is applied into soil, \%C value increases between 50 and $286 \%$ as compared to the control soil. In agricultural production applications, optimal plant growth in the soil is associated with the physical and chemical indicators of the soil structure.

Analysis of variance for the properties showed that the difference between the mean of at least two groups was statistically significant. The difference between the means shown by the same letter is not significant in its own group.

The most used application to modulate the physical parameters of the soil and maintain its continuity is the addition of organic materials into the soil (Bender et al., 1998). Organic wastes modulate the properties of the soil structure, and provide plant nutrients such as $\mathrm{P}, \mathrm{K}, \mathrm{Ca}, \mathrm{Mg}, \mathrm{Cu}$ and $\mathrm{Zn}$, especially $\mathrm{N}$. When biochar obtained from poultry is applied to soil of the tomato plant, the value of organic material increases (Akça and Naml1, 2015). Çengel et al. (2009) reported in their study at the organic vineyard region in Manisa that the amount of organic material in the soil with neutral reaction is low; however, additive green manure increase the amount of organic material, and the amount of organic material may yield better results when supported with materials of organic origin. The effects of the application on total $\mathrm{N}$ have been found to be significant $(\mathrm{p}<0.01)$. Different doses of biochar and animal manure applications increased the \% total $\mathrm{N}$ amount of the soil; and total $\mathrm{N}$ values were between $0.10-0.17 \%$ (Table 3). The lowest value was at control application, the highest was at $\mathrm{BC}_{10}+\mathrm{AM}_{5}$ application; this application yielded $70 \%$ increase 
Table 3. The effects of biochar and animal manure applications on the soils organic matter $(\%)$, total $N$, available $P$ and extractable $K$ contents

\begin{tabular}{c|c|c|c|c}
\hline Applications & Organic matter (\%) & $\mathbf{N}(\boldsymbol{\%})$ & $\mathbf{P}(\mathbf{m g} / \mathbf{k g})$ & $\mathbf{K}(\mathbf{m g} / \mathbf{k g})$ \\
\hline Control & $1.80 \mathrm{c}$ & $0.10 \mathrm{e}$ & $2.5 \mathrm{~d}$ & $315 \mathrm{~d}$ \\
$\mathrm{BC}_{5}+\mathrm{AM}_{5}$ & $5.10 \mathrm{bc}$ & $0.14 \mathrm{bc}$ & $3.8 \mathrm{c}$ & $408 \mathrm{c}$ \\
$\mathrm{BC}_{5}+\mathrm{AM}_{10}$ & $6.07 \mathrm{ab}$ & $0.11 \mathrm{de}$ & $4.9 \mathrm{bc}$ & $373 \mathrm{c}$ \\
$\mathrm{BC}_{10}+\mathrm{AM}_{5}$ & $6.39 \mathrm{ab}$ & $0.17 \mathrm{a}$ & $4.3 \mathrm{bc}$ & $408 . \mathrm{c}$ \\
$\mathrm{BC}_{10}+\mathrm{AM}_{10}$ & $5.72 \mathrm{ab}$ & $0.13 \mathrm{~cd}$ & $4.5 \mathrm{bc}$ & $380 \mathrm{c}$ \\
$\mathrm{BC}_{15}+\mathrm{AM}_{5}$ & $5.30 \mathrm{abc}$ & $0.15 \mathrm{ab}$ & $6.3 \mathrm{a}$ & $554 \mathrm{a}$ \\
$\mathrm{BC}_{15}+\mathrm{AM}_{10}$ & $6.92 \mathrm{a}$ & $0.15 \mathrm{abc}$ & $4.2 \mathrm{bc}$ & $511 \mathrm{ab}$ \\
$\mathrm{BC}_{20}$ & $6.68 \mathrm{ab}$ & $0.16 \mathrm{ab}$ & $5.4 \mathrm{ab}$ & $477 \mathrm{~b}$ \\
$\mathrm{AM}_{20}$ & $5.82 \mathrm{ab}$ & $0.12 \mathrm{de}$ & $4.6 \mathrm{bc}$ & $385 \mathrm{c}$ \\
\hline & $\mathrm{LSD}(\mathrm{p}<0.005)$ & $\mathrm{LSD}(\mathrm{p}<0.001)$ & $\mathrm{LSD}(\mathrm{p}<0.001)$ & $\mathrm{LSD}(\mathrm{p}<0.001)$ \\
& 0.8149 & 0.01028 & 0.65162 & 27.4485 \\
\hline
\end{tabular}

Besides, there has been an effective increase in a short time in test pots with biochar + animal manure. When pine biochar was added into the soil, the useful elements of the material such as N, P, K, Ca, Fe, Mn and $\mathrm{Zn}$ increased, biochar plus $\mathrm{N}$ application supported plant growth (Sohi et al., 2009; Van Zwieten et al., 2010).

Different doses of biochar and animal manure applications increased the amount of available $\mathrm{P}$ in the soil. The available $\mathrm{P}$ values are between $2.5-6.3 \mathrm{mg} \mathrm{kg}$ in the test soils. The lowest value was at control application, the highest was at $\mathrm{BC}_{15}+\mathrm{AM}_{5}$ application (Table 3); this application yielded 2,5 fold increase in total $\mathrm{N}$ values. This application yielded 1.13 unit increase of the soil $\mathrm{pH}$. According to CFA (California Fertilizer Association, 1995), the highest $\mathrm{pH}$ range is 6-7.5 for available phosphor, and the phosphor values in the study were in line with this range. When biochar is applied to soil of the sugar cane, the amount of total phosphor and total dissolved phosphor increase (Alvares-Campos et al., 2018).

Different doses of biochar and animal manure applications increased the amount of available $\mathrm{P}$ in the soil; and the values of extractable $\mathrm{K}$ in the soil was between 315-554 mg kg-1 (Table 3). Like 2 other nutrition element contents, the lowest value was at control application, the highest was at $\mathrm{BC}_{15}+\mathrm{AM}_{5}$ application; this application yielded $76 \%$ increase. The increase of the extractable $\mathrm{K}$ value in the soil was thought to be associated with the high extractable $\mathrm{K}$ value in the biochar and animal manure. Several researches reported that the amount of extractable $\mathrm{K}$ in the soils ranges between 40-150 $\mathrm{mg} \mathrm{kg}{ }^{-1}$ and no nutrition problem would appear if the extractable $\mathrm{K}$ was $150 \mathrm{mg} \mathrm{kg}^{-1}$ (Barber, 1985; Namlı et al., 2017).

\section{Conclusion}

In general, biochar and manure applications have positive effects on soil biological properties and nutrient content. The statistical evaluation of the enzyme analyses showed that the effects of applications on the enzyme activities of dehydrogenase, urease and arylsulphatase were significant $(\mathrm{p}<0.01)$. Dehydrogenase enzyme activity is highest at $\mathrm{BC}_{10}+\mathrm{AM}_{5}$ application, urease enzyme activity is highest at $\mathrm{BC}_{5}+\mathrm{AM}_{5}$ and $\mathrm{BC}_{15}+\mathrm{AM}_{5}$ applications, arylsulphatase enzyme activity as well as urease enzyme 
activity is highest at $\mathrm{BC}_{5}+\mathrm{AM}_{5}$ application. The statistical evaluation of alkaline phosphatase enzyme activity showed that the effects of the application was found to be insignificant. And it was identified that the highest numeric increase was at $\mathrm{BC}_{20}$ application. When the values of organic material in the soils were evaluated, it was identified that biochar and animal manure applications increased the amount of organic material in the soil as compared to control, and the highest values were obtained in the $\mathrm{BC}_{15}+\mathrm{AM}_{10}$ application. Mixing of these two materials (organic material and a material with high organic content) in the soil increased the amount of the organic materials in the soil, as expected. When the nutrition contents of the soils were evaluated, biochar and animal manure applications increased the values of total $\mathrm{N}$, available $\mathrm{P}$ and extractable $\mathrm{K}$; and the most effective doses were $\mathrm{BC}_{10}+\mathrm{AM}_{5}$ application for total $\mathrm{N}, \mathrm{BC}_{15}+\mathrm{AM}_{5}$ application for available $\mathrm{P}$ and extractable $\mathrm{K}$. It is thought that biochar has high $\mathrm{C}$ content and therefore $\mathrm{C} / \mathrm{N}$ ratio is not sufficient by itself and $\mathrm{C} / \mathrm{N}$ ratio is suitable with organic materials such as animal manure. Because these microorganisms living in soil organic materials because they contain plant nutrients like $\mathrm{N}$ and $\mathrm{P}$ in terms of their chemical stimulates wealth. As a result, the mineralization of the plant nutrients will be increased with the increase of biological activity in the soil. Due to the high content of biochar, the decomposition rate in the soil is low and it has been shown to be effective for a long time.

\section{REFERENCES}

[1] Akça, M. O., Namli, A. (2015): Effects of poultry litter biochar on soil enzyme activities and tomato, pepper and lettuce plants growth. - Eurasian Journal of Soil Science 4(3): 161 .

[2] Alvarez-Campos, O., Lang, T. A., Bhadha, J. H., McCray, J. M., Glaz, B., Daroub, S. H. (2018): Biochar and mill ash improve yields of sugarcane on a sand soil in Florida. Agriculture, Ecosystems \& Environment 253: 122-130.

[3] Anderson, T. H., Domsch. K. H. (1978): A physiological method for the quantitative measurement of microbial biomass in soils. - Soil Biology and Chemistry 10: 215-221.

[4] Aşkın, T., Kızılkaya, R., Gülser, C., Bayraklı, B. (2004): Some microbiological properties of campus soils of Ondokuzmayıs University. Ondokuzmayıs Üniversitesi kampus topraklarının bazı mikrobiyolojik özellikleri, O.M.Ü. - Ziraat Fakültesi Dergisi 191: 3136 .

[5] Azam, F., Malik, K. A., Sajjad, M. I. (1985): Transformations in soil and availability to plants of $15 \mathrm{~N}$ applied as inorganic fertilizer and legume residues. - Plant and Soil 861: 3-13.

[6] Barber, S. A. (1985): Potassium Availability at the Soil-Root Interface and Factors Influencing Potassium Uptake. - In: Munson, R. D. (ed.) Potassium in Agriculture. ASACSSA-SSSA, Madison, WI, USA: 309-324.

[7] Bender, D., Erdal, İ., Dengiz, O., Gürbüz, M., Tarakçığlu, C. (1998): The effects of different organic materials on some physical properties of clay soil (Farklı Organik Materyallerin Killi Bir Toprağın Bazı Fiziksel Özellikleri Üzerine Etkisi). - M. Tefik Yeşilsoy International Symposium on Arid Region Soil. 21-24 September, International Agrohydrology Research and Training Center, Menemen-Izmir, pp. 506-511.

[8] Bouyoucos, G. J. (1962): Hydrometer method improved for making particle size analysis of soil. - Agronomy Journal 545: 434-438.

[9] Bremner, J. M. (1965): Total Nitrogen 1. - In: Methods of Soil Analysis. Part 2. Chemical and Microbiological Properties. ASA, Madison, WI, pp. 1149-1178. 
[10] California Fertilizer Association (CFA) (1995): Agricultural productions/environmental concerns: new paradigms. - California Plant and Soil Conference, January 10-11.

[11] Çengel, M., Okur, N., Irmak Y1lmaz, F. (2009): The effect of green manures and farmyard manure on microbial activity in vineyard soils under organic management (Organik bağ topraklarında yeşil gübre bitkileri ve çiftlik gübresi uygulamalarının topraktaki mikrobiyal aktiviteye etkileri). - Ege University Faculty of Agriculture Journal 46(1): 25-31.

[12] Chunderova, A. I., Zubets, T. (1969): Phosphatase activity in dernopodzolic soils. Pochvovendenie 11: 47-53.

[13] Demisie, W., Liu, Z., Zhang, M. (2014): Effect of biochar on carbon fractions and enzyme activity of red soil. - Catena 121: 214-221.

[14] Gabriels, R., Verdonck, O. (1992): Method for measuring the water release curve of organic substrats. - Proc. Sym. Artificial Media in Horticulture, pp. 2054-2062.

[15] Glaser, B., Lehmann, J., Zech, W. (2002): Ameliorating physical and chemical properties of highly weathered soils in the tropics with charcoal-a review. - Biology and Fertility of Soils 35(4): 219-230.

[16] Isermeyer, H. (1952): Eine einfache Methode zur Bestimmung der Karbonate im Boden. - Zeitschrift für Planzenernährung, Düngung, Bodenkunde 561(3): 26-38.

[17] Kablan, N. (2005): Effect of different organic wastes on biological properties of soil and maize (Zea mays indendata) rhizosphere (Farklı Organik Atıkların Toprak Ve Misır (Zea Mays İndendata) Bitkisinin Rizosfer Bölgesindeki Biyolojik Özellikler Üzerine Etkisi). Yüksek Lisans Tezi Ondokuz Mayıs Üniversitesi Fen Bil. Ens. Toprak Bilimi ve Bitki Besleme Anabilim Dalı. Yayınlanmamış. 40 sf. Samsun.

[18] Kacar, B. (2009): Soil Analysis (Toprak analizleri). Extended Ed. II. - Nobel Publication, Istanbul.

[19] Kacar, B., Kütük, C. (2010): Fertilizer Analysis (Gübre analizleri). - Nobel Publication, Istanbul.

[20] Kambo, H. S., Dutta, A. (2015): A comparative review of biochar and hydrochar in terms of production, physico-chemical properties and applications. - Renewable and Sustainable Energy Reviews 45: 359-378.

[21] Kandeler, E., Gerber, H. (1988): Short-term assay of soil urease activity using colorimetric determination of ammonium. - Biology and Fertility of Soils 6(1): 68-72.

[22] Kayıkçığlu, H. H., Okur, N. (2013): Biochemical changes during composting of tannery sludge and assessment of compost quality (Deri sanayi aritma çamurunun kompostlaştırılması sırasındaki biyokimyasal değişiklikler ve oluşan kompostun kalitesi). - Anadolu Dergisi 22(2): 59-68.

[23] Kishimoto, S., Sugiura, G. (1980): Introduction to Charcoal Making on Sunday. - Sougou Kagaku Shuppan, Tokyo (in Japanese).

[24] Kizilaslan, H., Olgun, A. (2012): Organic agriculture and supports given to organic agriculture in Turkey (Türkiye'de organik tarım ve organik tarıma verilen desteklemeler). - Gaziosmanpaşa Üniversitesi Ziraat Fakültesi Dergisi 29(1): 1-12.

[25] Knudsen, D., Peterson, G. A., Pratt, P. F. (1982): Lithium, Sodium, and Potassium. - In: Methods of Soil Analysis. Part 2. Chemical and Microbiological Properties. ASA, Madison, WI, pp. 225-246.

[26] Lehmann, J. (2007): Bio-energy in the black. - Frontiers in Ecology and the Application 5(7): 381-387.

[27] Liang, B., Lehmann, J., Solomon, D., Kinyangi, J., Grossman, J., O’Neill, B., Skjemstad, J. O., Thies, J., Luizao, F. J., Peterson, J., Neves, E. G. (2006): Black carbon increases cation exchange capacity in soils. - Soil Science Society of America Journal 70: 17191730 .

[28] McClellan, A. T., Deenik, J., Uehara, G., Antal, M. (2007): Effects of flashed carbonized $\subset$ macadamia nutshell charcoal on plant growth and soil chemical properties. - American Society of Agronomy Abstracts 80(100): 120. 
[29] McLaughlin, H., Anderson, P. S., Shields, F. E., Reed, T. B. (2009): All biochars are not created equal, and how to tell them apart. - Proceedings, North American Biochar Conference, Boulder, Colorado, pp. 1-36.

[30] Moreno, J. L., Hernandez, T., Garcia, C. (1999): Effects of a cadmium-contaminated sewage sludge compost on dynamics of organic matter and microbial activity in an arid soil. - Biology and Fertility of Soils 28: 230-237.

[31] Müftüoğlu, N. M., Türkmen, C., Çıkılı, Y. (2012): Soil and plant fertility analysis (Toprak ve Bitkide Verimlilik Analizleri, Kriter Yayınevi). - Nobel, Ankara.

[32] Naml, A., Akça, M. O., Akça, H. (2017): The effects of biochars obtained from agricultural wastes on wheat plant growth and some soil properties (Tarımsal atıklardan elde edilen biyokömürün buğday bitkisinin gelişimi ve bazı toprak özellikleri üzerine etkileri). - Toprak Bilimi ve Bitki Besleme Dergisi 5(1): 39-47.

[33] Nannipieri, P., Ceccanti, B., Grego, S. (1990): Ecological significance of the soil biological activity in soil. - Soil Biochemistry 6: 415-471.

[34] Nelson, D. W., Sommers, L. E. (1982): Total Carbon, Organic Carbon and Soil Organic Matter. - In: Page, A. L. et al. (eds.) Methods of Soil Analysis. Part 2: Chemical and Microbiological Properties. ASA-SSSA, Madison, WI, pp. 539-579.

[35] Okur, N. (1997): Soil enzyme lecture notes. Toprak enzimleri ders notlar1. - Ege Üniversitesi Ziraat Fakültesi Toprak Bölümü, Bornova, İzmir.

[36] Olsen, S. R. (1954): Estimation of Available Phosphorus in Soils by Extraction with Sodium Bicarbonate. - United States Department of Agriculture; Washington.

[37] Özdemir, N., Kızılkaya, R., Sürücü, A. (2000): The effects of different organic wastes on urease enzyme activity of soils (Farklı organik atıkların toprakların üreaz enzim aktivitesi üzerine etkisi). - Ekoloji Çevre Dergisi 10(37): 23-26.

[38] Park, J. H., Choppala, G. K., Bolan, N. S., Chung, J. W., Chuasavathi, T. (2011): Biochar reduces the bioavailability and phytotoxicity of heavy metals. - Plant and Soil 348: (1-2) 439.

[39] Paz-Ferreiro, J., Gascó, G., Gutiérrez, B., Méndez, A. (2012): Soil biochemical activities and the geometric mean of enzyme activities after application of sewage sludge and sewage sludge biochar to soil. - Biology and Fertility of Soils 48(5): 511-517.

[40] Retan, G. A. (1915): Charcoal as a means of solving some nursery problems. - Journal of Forestry 13(1): 25-30.

[41] Roberts, K. G., Gloy, B. A., Joseph, S., Scott, N. R., Lehmann, J. (2009): Life cycle assessment of biochar systems: estimating the energetic, economic, and climate change potential. - Applicational Science \& Technology 44(2): 827-833.

[42] Ronsse, F., Van Hecke, S., Dickinson, D., Prins, W. (2013): Production and characterization of slow pyrolysis biochar: influence of feedstock type and pyrolysis conditions. - Gcb Bioenergy 5(2): 104-115.

[43] Schinner, F., Öhlinger, R., Kandeler, E., Margesin, R. (eds.) (1996): Methods in Soil Biology. Springer-Verlag, Berlin.

[44] Sepken, Berber, A., Farasat, S., Naml1, A. (2014): Afforestation effects on soil biochemical properties. - Eurasian Journal of Forest Science 1(1): 25-34.

[45] Sohi, S., Lopez-Capel, E., Krull, E., Bol, R. (2009): Biochar, climate change and soil: a review to guide future research. - CSIRO Land and Water Science Report 5(09): 17-31.

[46] Sun, Y., Gao, B., Yao, Y., Fang, J., Zhang, M., Zhou, Y., Chen, H., Yang, L. (2014): Effects of feedstock type, production method, and pyrolysis temperature on biochar and hydrochar properties. - Chemical Engineering Journal 240. 574-578.

[47] Tabatabai, M. A., Bremner, J. M. (1969): Use of p-nitrophenyl phosphate for assay of soil phosphatase activity. - Soil Biology and Biochemistry 1(4): 301-307.

[48] Tabatabai, M. A., Bremner, J. M. (1970): Arylsulfatase activity of soils. - Soil Science Society of America Journal 34: 225-229.

[49] Thalman, A. (1968): Zur Medhodik der Bestimmung der Dehydrogenase Aktivität im Boden mittels Triphenyltetrazoliumchlorid (TTC). - Landwirtsch. Forsch 21: 249-258. 
[50] U.S. Salinity Laboratory Staff (1954): Diagnosis and Improvement of Saline and Saline and Alkali Soils. - Agri. Handbook No. 60. U.S. Salinity Laboratory, Riverside, CA.

[51] Van Zwieten, L., Kimber, S., Morris, S., Downie, A., Berger, E., Rust, J., Scheer, C. (2010): Influence of biochars on flux of $\mathrm{N}_{2} \mathrm{O}$ and $\mathrm{CO}_{2}$ from Ferrosol. - Soil Research 48(7). 555-568.

[52] Von Liebig, J. (1878): Chemische Briefe. - Winter, Heidelberg. 